\title{
CONTRACTUAL TERMS AND CONDITIONS IN THE CONTEXT OF THE PUBLIC PROCUREMENT PRINCIPLES AND LEGAL COMPETENCE OF THE PUBLIC PROCUREMENT OFFICE IN SLOVAKIA ${ }^{1}$
}

\author{
Peter Lukáčka \\ Comenius University in Bratislava, Faculty of Law \\ Peter Kubolek \\ Public Procurement Office
}

\begin{abstract}
This article focuses particularly on identifying the limits of the problematic aspects of the formulation of the contract proposal or contractual terms and conditions as a part of the tender documents in the context of compliance with the principles of non-discrimination, economy and efficiency in public procurement. The authors concentrate on assessing the possibility of carrying out the supervision activities of the Public Procurement Office in reviewing the above mentioned categories of tender documents in order to ensure the fulfilment of the basic principles of public procurement.
\end{abstract}

Keywords: public procurement, basic principles, contract, terms, conditions, public procurement office, legal competence, Slovakia

\section{INTRODUCTION}

The field of public procurement regulation and its consistent application are currently the key pillars of ensuring the efficient and cost-effective management of public funds. Although several systemic changes have been implemented in this area in the recent time in order to ensure that these objectives are effectively put into practice in the public procurement process - as set out in the recitals of the Directive 2014/24/EU of the European Parliament and of the Council of 26 February 2014 on public procurement and repealing Directive 2004/18/EC, public procurement plays a key role in a strategy for smart, sustainable and inclusive growth, as one of the market-based instruments to be used to achieve smart, sustainable and inclusive growth while ensuring the most efficient use of public funds, and for that purpose, the public procurement rules adopted pursuant to Directive 2004/17/ EC of the European Parliament and of the Council and Directive 2004/18/EC of the European Parliament and of the Council should be revised and modernised in order to increase the efficiency of public spending, facilitating in particular the participation of small and medium-sized enterprises (SMEs) in public procurement, and to enable procurers to make better use of public procurement in support of common societal goals ${ }^{2}$ - this process is still considered (expressly by the general

1 This article has been prepared under project APVV-17-0641: Enhancing effectivity of Public Procurement Law and its Application in the Context of European Union Law (Zefektívnenie právnej úpravy verejného obstarávania a jej aplikácie v kontexte práva Európskej únie).

2 Cf. Point 2 of Preamble of Directive 2014/24/EU. 
public) to be a space where there is a presumption of increased risks for non-competitive behaviour and therefore the failure to respect the basic public procurement objective of saving resources from the public funds and avoiding unnecessary and excessive drawing and misuse.

On that ground, the authors of the text deal with the possibilities of the Public Procurement Office $(\mathrm{PPO})^{3}$ to carry out the supervision competency in the Slovak Republic conditions even in areas that are primarily determined by the regulation of private law (contract proposal, terms and conditions of contract), on the grounds that this can also be subject to an effective discrimination in the participation in public procurement of some potential candidates in such competitions which are not justified by a reasonable and acceptable interest of the contracting authority and which, in the light of their content, allow only a narrow range of tenderers to participate in the tendering procedure.

\section{PRINCIPLE OF NON-DISCRIMINATION, TRANSPARENCY, ECONOMY AND EFFICIENCY IN PUBLIC PROCUREMENT}

In order to achieve the objectives of the public procurement, a complex set of principles / fundamentals has been developed and the strict compliance with these objectives is to be ensured. In this sense, public procurement is to be carried out in accordance with the principles of the Treaty on the Functioning of the European Union (TFEU), and in particular the free movement of goods, freedom of establishment and the freedom to provide services, as well as the principles deriving therefrom, such as equal treatment, non-discrimination, mutual recognition, proportionality and transparen$\mathrm{cy}^{4}{ }^{4}$ These fundamental principles follow the primary objective of opening up public procurement to competition in order to its development and protection. ${ }^{5}$

According to the decision of the Supreme Administrative Court of the Czech Republic No. 5 Afs 131/2007 - 131 of 12/05/2008, "the European Court of Justice (ECJ) has developed a set of basic public procurement principles derived from the rules and fundamental principles of the EC Treaty (e.g. the principle of equal treatment and non-discrimination). The main purpose of public procurement regulation is to ensure that public funds are consumed properly and efficiently, based on earnest assessments and without any kind of financial or political advantage or reward. The principle of equal treatment is of particular importance for the award of public contracts. This principle includes equality of opportunity for all tenderers and the contracting authority must adhere to it at every stage of the procurement process. Its objective is to promote the development of sound and effective competition between the entities involved in the procurement procedure and therefore requires that all tenderers have the same opportunities when formulating the text of their tenders. It is therefore assumed that all competitors' offers are subject to the same conditions. Nor can it, in assessing the legal issues raised above, take into account ECJ case law, which implies that the principle of equal treatment implies a duty of transparency in order to verify whether that principle is complied with. Its aim is, essentially, to exclude the risk of preference and arbitrariness of the contracting authority. It implies that all terms and conditions of the award procedure are clearly, precisely and unambigu-

\footnotetext{
3 Pursuant to Section 140 (1) PPA, the Public Procurement Office is the central state administration authority for public procurement that pursuant to Section 147 (c) PPA oversees public procurement.

Cf. Point 2 of Preamble of Directive 2014/24/EU.

For more details see: Explanatory Report on Section 10 of Act no. 343/2015 Coll.
} 
ously specified in the contract notice or in the tender documents. The principle of transparency also presupposes that all technical information relevant for the proper understanding of the contract notice or the contract documentation is as early as possible provided to all the entities involved in the procurement procedure in a way which enables all reasonably informed tenderers to understand the exact scope of tender documents and its interpretation in the same way and complementary to enable the contracting authority to verify whether tenders meet the criteria governing the contract. The procedure whereby the contracting authority has set additional criteria or qualification prerequisites for participation in a public contract shortly before submitting, possibly only after the offer has been submitted, is generally considered to be unlawful (e.g. case C-470/99 Universelle-Bau Ag [2000] I-11617, case ATI EAC Srl and Viaggi di Maio Snc, C-331/04, 2005 I-10109)...

In order to transpose the related provisions of the Directive and to preserve the importance of these principles, the legislator adopted their explicit regulation in sec. 10 (2) of Act no. 343/2015 Coll. on Public Procurement and on amendments to certain laws (hereinafter referred to as the "Public Procurement Act" or "PPA"), in such a way that the contracting authority must comply with the principle of equal treatment, the principle of non-discrimination of economic operators, the principle of proportionality and the principle of economy and efficiency. ${ }^{6}$

We agree with the opinion that: "It is (in relation to the basic principles of public procurement) the basic ideas on which the whole public procurement process is built. At the same time, they serve as interpretative rules for the interpretation and application of individual provisions of the PPA not only by contracting authorities, contracting entities and subsidized contracting entities, but also by the PPO in the performance of supervision in public procurement."

As we have already pointed out in the text above, the principles of public procurement mainly follow the application and interpretative function in relation to the entire procurement process. ${ }^{8}$

In this sense, the principle of non-discrimination can be regarded as one of the building blocks of the proper running of public procurement, the proper application of which is to ensure that the contracting authority, contracting entity does not favour certain suppliers or groups of suppliers at the expense of others without pre-set rules and without complying with the subject and the nature of the public contract and it is also not possible to favour a supplier on the basis of its seat. ${ }^{9}$ It may be mentioned at this point that there is some controversy among public procurement professionals in the subject of defining the relationship between the principle of equal treatment and the principle of non-discrimination when the legislator in the Explanatory Report to Act No. 343/2015 Coll. states that "the principle of equal treatment is a particular specification of the more general principle of non-discrimination".

On the other hand, some authors see this relationship differently and are of the opinion that "The principle of non-discrimination of economic operators, as we have already outlined, is, in our opinion, a special principle in relation to the principle of equal treatment, not the way the legislator expressed in the Explanatory Report to Act (...) The specificity of the principle of non-discrimination lies most of all in the prohibition of discrimination on grounds of nationality, which the application

6 Legislator in the Czech Republic has adopted the similar approach to these principles. Cf. the wording of Section 6 of Act no. 137/2006 Coll. of the Public Procurement Act.

7 PÚČEK, L. - ZAMIŠKOVÁ, A.: Verejné obstarávanie. Podlimitné zákazky v praxi. Bratislava: Wolters Kluwer, 2015, p. 13.

8 To the definition of the application and interpretative function of the public procurement principles, see: JURČÍK, R.: Zákon o veřejných zakázkach. Komentář. 4. vydání. Praha: C.H. Beck, 2015, p. 90-91.

9 KRUTÁK, T. - KRUTÁKOVÁ, L. - GERYCH, J.: Zákon o zadávaní veřejných zakázek s komentářem k 1. 10. 2016. Olomouc: ANAG, 2016, p. 51. 
practice often neglected and misinterpreted the characteristics of the breach of the principle of equal treatment with the principle of non-discrimination, thus negating its specific nature." ${ }^{10}$

According to the decision of the Supreme Court of the Slovak Republic No. 3 Sžf 129/2013 on $25 / 11 / 2014$, "the principles of transparency and equal treatment are governed by all procurement procedures and, in that meaning, the substantive and procedural conditions for public procurement selection criteria must be clearly and previously defined and require to be made public, so the concerned subjects can know exactly the limitations of the procedure and the concerned subjects are certain the same restrictions apply to all competitors."

The definition of the principles of economy and efficiency in public procurement can be carried out through the purpose fulfilment of which the use is primarily intended to be implemented and which is not only for contracting authority / contracting entity to purchase only the cheapest goods, services or works but to obtain the best value generated in the competitive environment. ${ }^{11}$

We believe that the principle of economy and efficiency could also be applied to issues that arise only after the successful conclusion of public procurement, but these issues are closely related to the process due to its purpose and it includes particular situation the contract is found invalid, the consequence of which leads to the additional costs of the procurement of the goods.

\section{LIMITS OF THE SUPERVISION COMPETENCY OF THE PUBLIC PROCUREMENT OFFICE IN PROPOSAL FOR A CONTRACT AND CONTRACTUAL TERMS AND CONDITIONS REVIEW}

In accordance with sec. 42 (11) of the Public Procurement Act, proposal for a contract and contractual terms and conditions is an important part of the tender documents. ${ }^{12}$ The importance of these must be particularly seen in the context of the fact that a contract resulting from a public procurement and concluded in a singular case, shall not be interfered with the tender documents, nor proposal for a contract and/or contractual terms and conditions as a part of tender documents. In this meaning, we as well recognise the main reason why, in our view, it is necessary to examine questions relating to this particular part of tender documents because it includes possibility based on a specific expression of some contractual terms and conditions to de facto discourage some of the tenderers from participating in a competition, who might otherwise contribute to the reach of the public procurement goals.

As an example, it is possible to set out in this context the provisions of the contractual terms which affect the way and variability of a contract assurance, which may be expressed in the range of the requested assurance in combination with facultative execution or in the instituting of so-called contract guarantee, ${ }^{13}$ and so on. As another example may be stated the arrangement of payment for

10 TKÁČ, J. - GRIGA, M.: Zákon o verejnom obstarávaní - velký komentár. Bratislava : Wolters Kluwer, 2016, p. 233.

11 Ibid p. 237-238.

12 Section 42 (1) of Act no. 343/2015 Coll. on Public Procurement and on the Amendment of Certain Acts as amended: "tender documents contain documentation, plans, models or photographs if they are necessary to draw up a tender, criteria for the evaluation of tenders, rules of their application and instructions for drawing up and submitting tenders. The tender documents also contain a draft contract or a draft framework agreement, the content of which may be determined by reference to the General Commercial Terms and Conditions... ".

13 To the conditions for determining tender bond see: Analýza rozhodnutia Rady týkajúceho sa zmluvnej zábezpeky (Analysis of the Council of Office decision on contract guarantee). Available at the Public Procurement Office's website: https:// www.uvo.gov.sk/vsetky-temy-4e3.html? id $=299$ (accessed on $5^{\text {th }}$ November 2018). 
carrying out the contract (e.g. splitting the price-payment to successful tenderer for dozens of payments over a longer period of time $\left.{ }^{14}\right)$.

The above examples of contractual terms and conditions expressions (possibly related to other factors) may already discourage multiple tenderers from participating in a singular procurement procedure, although they would otherwise be suitable and capable suppliers of the performance that is the object of a public procurement procedure.

In this regard, we consider it necessary to present the PPO's approach to this issue, which to its scope of supervision competency in contractual terms and conditions review in relation to the previous Act on Public Procurement (Act No. 25/2006 Coll. on Public Procurement and on the amendment to some acts) stated:

"The supervision competency of the Public Procurement Office is limited to examining the compliance with the Public Procurement Act, particularly its principles, but not for examining compliance with commercial, civil or other public laws. The tenderer is obliged to accept the expression of the proposal contractual terms and conditions, which are part of the tender documents." ${ }^{\text {15 }}$

Similarly, the PPO also stated in its Explanatory Opinion on the present-day legislation (Act No. 343/2015 on Public Procurement and on the amendment of some laws):

"The Public Procurement Office (hereinafter referred to as "the Office") does not examine the compliance of contractual terms and conditions with commercial, civil or other public law. In these cases, the supervision competency of the Office is limited to examining the compliance of the contractual terms and conditions with the Public Procurement Act, particularly with its principles, in view of whether the contracting authority / entity / person under sec. 8 of the Public Procurement Act has set the terms and conditions for all tenderers in compliance with the principle of transparency, non-discrimination and the principle of equal treatment. (...) Examination of the compliance of contractual terms and conditions with commercial, civil or other public laws falls under the protection of other specialized state bodies, therefore, the Office has limited access to contractual freedom and contracting liberty of the contracting authority / entity / person under sec. 8 of the Public Procurement Act only in the scope of examining the compliance of the contractual terms and conditions with the Public Procurement Act, particularly with its principles." 16

In this meaning, the approach of the PPO appears to be consistent, but the authors consider it necessary in order to identify the limits of the Office's scope to focus on a more precise determination of the boundary determining whether the Office will or will not examine the components (parts) of the tender documents - contractual terms and conditions.

We believe that the examples above of contractual terms and conditions (even on the basis of significant decisions of the Office) may ultimately be considered as incompatible with the principles of procurement (in particular the principles of non-discrimination and proportionality) and, therefore, in complying with other legal conditions, also derive the supervision competency of the PPO.

\footnotetext{
14 As an example of this contract condition, we mention "The parties have agreed that the total price of a work, including VAT, as provided for in Article 5, shall be paid by the buyer on the basis of an invoice pursuant to Article 6, in 120 regular monthly instalments..." For more details see the decision of the Public Procurement Office no. 5728-6000/2018-OD dated 15 June 2018 - decision of the Office in a similar case (decision no. 6335-6000/2018-OD dated 15 June 2018) is subject to second-instance proceedings before the Council of the Office, the legal opinion of the Office is hence, at the time of writing of this article, not yet confirmed by a second-instance decision.

15 Explanatory Opinion of the PPO no. 1/2013 from 2 January 2013.

16 Explanatory Opinion of the PPO no. 3/2016 from 15 April 2016.
} 
On the other hand, we believe that the competency of the PPO does not need to end/stop at the reviewing the terms and conditions accordingly, but we also wish to dispute about its competence to review the contractual terms and conditions from the aspect of their compliance with the provisions of other legislation, e.g. Commercial Code, respectively Civil Code, in so far as it relates to such contractual requirements, the failure of which could lead to the invalidity of the contract resulting from the public procurement process, in order to achieve and develop the principle of economy and efficiency of public procurement.

In this regard, we agree with J. Duračinská, who states: "It is clear from the law of the public procurement process and the principles applicable to public procurement that the procurement process does not end with the choice of a contractor from among the tenderers and the conclusion of the contract but it continues also with the impact on the content of the contract relationship and the possibility of its modification." 17

This leads us to a consequence that in case of the event that the successful conclusion of the public procurement process would result in the conclusion of the contract, the content of which would comply with the tender documents, but at the same time this would be contrary to the mandatory provisions of other relevant legislation, it would probably be necessary to eliminate unlawfulness. In this way, the whole process would probably be questioned and public procurement would probably have to be re-noticed. ${ }^{18}$ We assume that the very principle of economy and efficiency of public procurement could be a clear justification for PPO to deal more closely with contractual terms and conditions in order to prevent situations which can significantly increase the costs accompanying the procurement process.

However, in this context, it is also essential to say that this competence could, under current legal circumstances, raise a number of questions, particularly whether or not the PPO has the competence to review the validity or invalidity of the proposed contract and whether or not only court of law has that competence. If such a question should be considered in the administrative proceedings before the PPO as a preliminary question under sec. 40 of Act no. 71/1967 Coll. (Code of Administrative Procedure), primarily it is necessary to correctly consider the applicability of that provision of the Code of Administrative Procedure in relation to the provisions of sec. 185 of the Public Procurement Act. Under Section 40 (1) of the Code of Administrative Procedure, there are three ways in which the administrative body can solve the preliminary question:

1. where a question has already been raised in the proceedings, which the competent body has already rightly decided, the administrative body shall be bound by such a decision;

2. otherwise, the administrative body is allowed to make a judgment on such a matter or

3. the administrative body gives the competent authority a call to initiate the procedure.

In the case of the application of the second method, "it is settled case-law that the administrative authority ruling the case is not only entitled but also obliged to deal with preliminary questions if

17 DURAČINSKÁ, J.: Ingerencia procesu verejného obstarávania na zmluvy uzatvorené na základe tohto procesu. In: Acta Facultatis Iuridicae Universitatis Comenianae, Tomus XXXIII, 1/2014. Bratislava: Comenius University in Bratislava, Faculty of Law, 2014, p. 6.

18 According to the first sentence of Point 110 of Preamble of Directive 2014/24/EU, in line with the principles of equal treatment and transparency, the successful tenderer should not, for instance where a contract is terminated because of deficiencies in the performance, be replaced by another economic operator without reopening the contract to competition. Similarly, pursuant to Article 72 (5) of Directive 2014/24 /EU, a new procurement procedure in accordance with this Directive shall be required for other modifications of the provisions of a public contract or a framework agreement during its term than those provided for under paragraphs 1 and 2 . 
they are present in the proceedings. According to the decision of the Supreme Administrative Court (A 3270/24), the administrative body cannot refuse to judge the merit of the case on the ground that the preliminary question has not yet been decided by the competent authority. Either the administrative body will answer the question itself (make a judgment on it) or it gives the competent authority a call to initiate the procedure and awaits with its own decision until the decision on the preliminary question is made. According to sec. 40 of the Code of Administrative Procedure, the administrative body has a fundamental discretion in considering which of these two options it will choose (this freedom could be limited by a specific law only). This means that the administrative body is never allowed to remain passive in relation to the preliminary question." ${ }^{19}$

However, this legal opinion is "relativized" by the decision of the Supreme Court of the Slovak Republic no. 6Sžo/229/2010 dated 20 July 2011, according to which if a dispute as to the validity of the repudiation of contract arises, in practice, particularly because of the fulfilment or non-fulfilment of the legal or contractual conditions for such a procedure, this constitutes a civil litigation, on which only a court of law is entitled to rule (sec. 7 (1) of the Code of Civil Procedure). Since, according to this decision of the Supreme Court, the administrative body (cadastral administrative body in this particular case) is not entitled to judge the validity of the repudiation of contract nor as a preliminary question (sec. 40 of the Code of Administrative Procedure), this must be reflected in the following procedure - if the validity of the repudiation of the contract is questioned by the other party, the administrative body should give a call to the other party to take an action of the legal procedure to competent court of law within the specified period of time (sec. 80 (c) of the Civil Procedure Code), stating that if it fails to do so, it will be considered as "acceptance" of validity of the repudiation of the contract.

\section{CONCLUSION}

The supervision competency of the Public Procurement Office shall be seen primarily through the purpose of public procurement and its principles, which should be protected by the Office. In this meaning, it is necessary to take into account the fact that, from the point of view of the conclusion of a contract resulting from a public procurement procedure, other than the normal business principles typical for the area governed by commercial law apply (e.g. freedom of contract, etc.) and these principles are undermined in the public procurement process by the fact that the legislator, within the framework of the rules governing this process, seeks to form a legal framework that will lead all stakeholders to handle public funds economically, efficiently and effectively. We assume, for that purpose, de lege ferenda it would be appropriate to consider a legislation that would undoubtedly enable the Public Procurement Office to review the content of the contractual terms and conditions not only to a limited extent, namely regarding the principles of public procurement, but also the compliance of contractual terms and conditions with mandatory provisions of other legal regulations, the failure of which can result in repeating of the procedure, which we consider undesirable in terms of cost efficiency. At the same time, we find it necessary to consider elaboration of sample contract terms and conditions that could be valuable to contracting authorities or entities and contribute to the elimination (reduction) of current application problems.

19 KOŠIČIAROVÁ, S.: Správny poriadok - komentár s novelou účinnou od 1. januára 2004. Šamorín: Heuréka, 2004, p. 166. 


\section{Bibliography:}

Analysis of the Council of Office decision on contract guarantee (Analýza rozhodnutia Rady týkajúceho sa zmluvnej zábezpeky). Available at the Public Procurement Office’s website: https://www.uvo.gov.sk/vsetky- temy-4e3. html?id=299 (accessed on $5^{\text {th }}$ November 2018).

DURAČINSKÁ, J.: Ingerencia procesu verejného obstarávania na zmluvy uzatvorené na základe tohto procesu. In: Acta Facultatis Iuridicae Universitatis Comenianae, Tomus XXXIII, 1/2014. Bratislava: Univerzita Komenského, Právnická fakulta, 2014, ISSN 1336-6912

JURČÍK, R.: Zákon o veřejných zakázkach. Komentář. 4. vydání. Praha: C.H. Beck, 2015, ISBN 978-80-7400-505-3

KOŠIČIAROVÁ, S.: Správny poriadok - komentár s novelou účinnou od 1. januára 2004. Šamorín: Heuréka, 2004, ISBN 80-89122-14-0

KRUTÁK, T. - KRUTÁKOVÁ, L. - GERYCH, J.: Zákon o zadávaní veřejných zakázek s komentářem k 1. 10. 2016. Olomouc: ANAG, 2016, ISBN 978-80-7554-040-9

PÚČEK, L. - ZAMIŠKOVÁ, A.: Verejné obstarávanie. Podlimitné zákazky v praxi. Bratislava: Wolters Kluwer, 2015, ISBN 978-80-8168-123-3

TKÁČ, J. - GRIGA, M.: Zákon o verejnom obstarávaní - velký komentár. Bratislava: Wolters Kluwer. ISBN 978-80-8168-455-5

Decision of the PPO no. 5728-6000/2018-OD from 15 June 2018

Decision of the PPO no. 6335-6000/2018-OD from 15 June 2018

Decision of the Supreme Court of the Slovak Republic no. 6Sžo/229/2010 from 20 July 2011

Explanatory Opinion of the PPO no. 1/2013 from 2 January 2013

Explanatory Opinion of the PPO no. 3/2016 from 15 April 2016

\section{Contact information:}

JUDr. Peter Lukáčka, PhD.

peter.lukacka@flaw.uniba.sk

Univerzita Komenského v Bratislave, Právnická fakulta

Šafárikovo nám. č. 6

81000 Bratislava

Slovak Republic

JUDr. Peter Kubolek

peter.kubolek@uvo.gov.sk

Úrad pre verejné obstarávanie (Public Procurement Office)

Ružová dolina 10

82109 Bratislava

Slovak Republic 